\section{Correlation between metabolic syndrome and lower urinary tract symptoms}

Djordje Argirović ${ }^{1}$, Aleksandar Argirović ${ }^{2}$

${ }^{1}$ Oupatient Clinic „Argirović“, Urology, Belgrade, Serbia

${ }^{2}$ Clinical Hospital Center ,Zemun-Belgrade“, Department of Urology, Zemun, Serbia

\section{Abstract}

Middle-aged men often have lower urinary tract symptoms (LUTS) resulting from benign prostatic enlargment (BPE). The correlation between metabolic syndrome (MS) and BPE remain debatable. The aim of the present study is to investigate the impact of MS on LUTS in a middle-aged men receiving a health checkup. Males aged $>45$ years who voluntary underwent a medical checkup were enrolled in this study. All participants were stratified into 2 groups by the presence of 3 or more risk factors of MS including elevated blood pressure, waist circumference (WC), serum fasting glucose (SFG), high density lipoproteins cholesterol (HDL-C) and triglyceride (TG. Prostate volume (PV), determinated by TRUS, and PSA level were used for subrgroup analysis, including determination of total International Prostate Symptom Score (IPSS), with voiding and storage score, and quality of life (QOL) score.Three hundred fifty four men, with mean age 55.6 \pm 9.72 years, were enrolled into the study. According to reporting criteria of MS, $108(30.5 \%)$ had MS and formed the study group, whereas 246 (69.5\%) MSnegative men formed a control group. Antrpometric, metabolic outcoms and percentage of hypertension were significantly higher in MS vs non-MS group. The MSgroup had lower mean total IPSS ( $7.83 \pm 6.63$ vs 6.85 $\pm 6.25, \mathrm{p}=0.05)$, lower severity of weak urinary stream $(1.24 \pm 1.60$ vs $0.95 \pm 1.50, \mathrm{p}=0.021)$ and lower severity of IPSS grading $(\mathrm{p}<0.014)$. In the larger PV $(>30 \mathrm{~mL})$, total IPSS, storage score, voiding frequency, urgency and incomplete emptying were lower in the MS group $(p<0.05)$. In the higher PSA $(>0.93 \mathrm{ng} / \mathrm{mL})$ group men with MS had significantly lower IPSS, voiding score and less reporting of incomplete emptying and weak urinary stream. Men in the MS group were stratified into 3 groups according to the number of MS risk factors (3, 4 and 5) and their LUTS score was compared to that of non-MS group. The negative association between voiding score, storage score, severity of LUTS and MS became particularly pronounced as the number of MS

\section{Korelacija između metaboličkog sindroma i simptoma donjih partija urotrakta}

Đorđe Argirović ${ }^{1}$, Aleksandar Argirović ${ }^{2}$

${ }^{1}$ Poliklinika „Argirović“", Urologija, Beograd, Srbija

${ }^{2}$ Kliničko Bolnički Centar ,Zemun-Beograd“, Služba urologije,

Zemun, Srbija

\section{Apstrakt}

Sredovečni muškarac često ima simptome donjih partija urotrakta (SDPU) kao posledice benignog uvećanja prostate (BUP). Korelacija između metaboličkog sindroma (MS) i SDPU ostaje predmet debate. Ova studija ima za cilj da ispita uticaj MS na SDPU kod sredovečnih muškaraca imali opšti lekarski pregled. Svi pacijenti su podeljeni u 2 grupe u zavisnosti od prisustva 3 ili više faktora rizika uključujući povišen krvni pritisak, obim struka, glikemiju,HDL holesterol i trigliceride. Volumen prostate (VP), određen pomoću transrektalnog ultrazvuka, i nivo prostata specifičnog antigena (PSA) su upotrebljeni za podgrupnu analizu, uključujući odredjivanje ukupnog Internacionalnog Prostata Simptom Skora (IPSS), sa iritativnim i opstruktivnim skorom, kao i ocenu kvaliteta života. Tri stotine pedeset četiri muškarca, srednje starosti $55.6 \pm$ 9.71 godina, su uključeni u studiju. U zavisnosti od navedenih kriterijuma za MS, 108 (30.5\%) je imalo MS i predstavljalo je studijsku grupu, dok je 246 (69.5\%) MS-negativnih muškaraca formiralo kontrolnu grupu. Antropometrijski indeksi, metabolički parametri i učestalost arterijskie hipertenzije su bili veći kod grupe sa MS u odnosu na grupu bez MS ( $\mathrm{p}<0.0001)$. Grupa sa MS $(7.89 \pm 6.63$ prema $6.85 \pm 6.52)$ je imala manju srednju vrednost ukupnog IPSS, manju slabost mlaza urina pri mokrenju (1.24 \pm 1.60 prema $0.95 \pm 1.50, \mathrm{p}=0.021)$ i manji stepen IPSS gradiranja $(\mathrm{p}=0.014)$. Kod većeg VP $(>30 \mathrm{~mL})$, ukupni IPSS, iritativni i opstruktivni skor, urgentni pozivi na mokrenje i nepotpuno pražnjenje bešike su bili manje izraženi kod grupe sa MS $(\mathrm{p}<0.05)$. U grupi sa višim prostata specifičnim antigenom (PSA) $(>0.93 \mathrm{ng} /$ $\mathrm{mL}$ ), muškarac sa MS je imao značajno niži IPSS, opstruktivni skor, nepotpuno pražnjenje mokraćne bešike i slab mlaz. Negativna povezanost izmedju iritativnih i opstruktivnih smetnji, intenzitet SDPU i MS postaje naročito izražena sa povećanjem broja faktora rizika MS ( $p<0.0001)$. Odnos šanse (OŠ) za 
factors increased. The odds ratio (OR) for moderate to severe LUTS was significantly lower in men with 3 (OR 0.61, 95\% confidence interval (CI) 0.40-0.94) or 5 ( OR $0.32,95 \%$ CI $0.11-0.95$ ) MS risk factors. Men in the MS group were less likely to experience moderate to severe LUTS (OR $0.58,95 \%$ CI 0.41 $0.83)$. We confirmed that MS had favorable effects in LUTS, including voiding and storage symptoms in healthy middle-aged men. This beneficial effect was most significant in men with enlarged prostate and/or high PSA level.

Key words: metabolic syndrome, lower urinary tract symptoms, prostate volume, prostate specific antigen umeren i izražen SDPU je bio signifikantno manji kod muškaraca sa 3 (OŠ 0.61; 95\% interval poverenja (IP) 0.40-0.94) ili 5 (OŠ 0.32; 95\% IP 0.11-0.95) faktora rizika. Muškarci u grupi sa MS imaju manju verovatnoću da imaju umeren do žestok skor SDPU (OŠ 0.58; 95\% IP 0.41-0.83). Studija je pokazala da MS ima povoljan efekt na SDPU, uključujući iritativne i opstruktivne simptome kod zdravih sredovečnih muškaraca. Beneficirajući efekat je bio najizraženiji kod muškaraca sa uvećanom prostatom i/ili višim vrednostima PSA.

Ključne reči: metabolički sindrom, simptomi donjih partija urotrakta, volumen prostate, prostata specifični antigen

\section{Introduction}

Middle-aged men often have LUTS resulting from BPH1. The MS is thought to affect male prostate growth and correlation between severity of male LUTS and MS components have been reported2,3. However, emerging evidence indicates that MS is not indenpendently associate with either the pathogenesis or severity of LUTS in healthy middle-aged and elderly men4-7. Indeed, the early stage of hyperinsulinemia may have a fovorable effect on male LUTS8. Thus, because the relationship between MS and LUTS in healthy middle-aged men remain unclear, we sought to investigate the impact of MS on LUTS in such a population.

\section{Material and methods}

Males aged $>45$ years who vuluntary underwent a medical check up were enrolled in this study. Written informed consent was obtain from each men before enlorment. Before examination, a self-administered questionnaire, was used to colect information about the participants' health, clinical symptoms, and medical and medication histories. Subjects were excluded from the study for any of thefollowing reasons: (1) use of hormone remplacement therapy or 5-ARI within last 6 months, (2) history of prostate cancer or prostatic surgery, (3) current use of medications known to interfere with voiding symptoms, such as anticholinergics, sympathomimetrics and sympatholytics. Between January 2010 and December 2012, 354 men with mean age $55.6 \pm 9.72$ years, entered into the study. Acording to reported criteria of MS, $108(30.5 \%)$ had MS and formed the study group, whereas 246 (69.5\%) MS-negative men, formed the control group. Basic clinical data, such as age, height, weight, blood pressure, and WC, as wel as basic biochemical profile and serum PSA levels were collected. Additionally, the IPSS questionnaire and QOLs score were assessed and recorded. A DRE and TRUS of the prostate were assessed to asesse the PV. All patients were stratified into 2 groups by the presence of MS risk factors.

\section{Definition of MS}

A diagnosis of MS had to satisfy 3 or more National Education Program- Adult Treatment Panel III (NEPATP III) Criteria including elevated blood pressure or receiving antihypertensive medications, WC, serum SFG and/or receiving antidiabetic drugs, HDL-C and TG and/or receiving antihypercholesterolemic drugs, with addition of body mass index (BMI), total cholesterol (T-C) and HbAlC as supplementary data. 


\section{Statistics}

Differences between groups in continous variables were analyzed with the $t$ test and presented as mean and $\mathrm{SD}$, whereas differences in categorical variables were analyzed with chi-square test. A p value of 0.05 was considered statistically significant. The results of the IPSS were further stratified by 2 covariate, namely PV and PSA level, using the median values as the cut-off points. A general linear model for analysis of covariance was performed with IPSS as a dependent variable, the number of MS risk factors as a fixed factors, and age as covariate. Multivariate regression analysis was used for testing the independent influence of major risk factors in the IPSS.

\section{Results}

The median age of study subjects with and without MS were 56.4 and 55.3 years, respectively. Antropometric, including BMI and WC, as well as metabolic outcomes (SFG, HbA1C,TG ) and percentage of hypertension were significantly higher in the MS vs non-MS group. The PV and intravesical prostatic growth were comparable between MS and non-MS group (Table 1.).

\begin{tabular}{|c|c|c|c|}
\hline & $\operatorname{MS}(n=108)$ & non-MS $(n=246)$ & $\mathrm{p}$ value \\
\hline & mean \pm SD & mean $\pm \mathrm{SD}$ & \\
\hline Age (years) & $56.4 \pm 10.1$ & $55.3 \pm 9.34$ & 0.18 \\
\hline Serum PSA & $1.55 \pm 2.10$ & $1.44 \pm 1.57$ & 0.44 \\
\hline \multicolumn{4}{|l|}{ Metabolic profile } \\
\hline Body mass index & $27.0 \pm 3.19$ & $24.2 \pm 3.10$ & $<0.001$ \\
\hline Waist circumference & $94.6 \pm 7.63$ & $87.1 \pm 7.16$ & $<0.001$ \\
\hline Hypertension & $87(85 \%)$ & $76(30.9 \%)$ & $<0.001$ \\
\hline Serum fasting glucose & $106 \pm 23.9$ & $93.2 \pm 15.9$ & $<0.001$ \\
\hline Serum $\mathrm{HbA} 1 \mathrm{C}$ & $6.02 \pm 0.78$ & $5.7 \pm 0.64$ & $<0.001$ \\
\hline Serum trigliceryde & $181 \pm 85.9$ & $111 \pm 60.0$ & $<0.001$ \\
\hline Serum HDL cholesterol & $40.2 \pm 8.81$ & $48.8 \pm 11.0$ & $<0.001$ \\
\hline Serum total cholesterol & $198 \pm 3.51$ & $201 \pm 33.7$ & $<0.001$ \\
\hline Prostate volume $(\mathrm{mL})$ & $31.4 \pm 14.4$ & $29.1 \pm 13.1$ & 0.15 \\
\hline \multicolumn{4}{|l|}{ Prostate size estimation $(\mathrm{mL})$} \\
\hline$<20$ & $20(18.5 \%)$ & $60(24.4 \%)$ & \\
\hline $20-30$ & $46(42.5 \%)$ & $97(39.0 \%)$ & \\
\hline $31-40$ & $28(25 \%)$ & $60(24.4 \%)$ & \\
\hline $41-50$ & $11(10.2 \%)$ & $20(8.1 \%)$ & \\
\hline$>51$ & $5(4.6 \%)$ & $9(3.7 \%)$ & \\
\hline Intravesical prostatic growth & $55(50.9 \%)$ & $125(50.8 \%)$ & \\
\hline
\end{tabular}

Table 1.: Basic demographics in 354 enrolled men categorized by MS

Compared to the the non-MS group, the MS group had lower mean total IPSS and severity of a weak urinary stream during voiding; furthermore, experienced lower severity of IPSS grading (Table 2.). 


\begin{tabular}{|l|c|c|c|}
\hline & MS $(\mathrm{n}=108)$ & non-MS $(\mathrm{n}=246)$ & $\mathrm{p}$ value \\
\hline & mean $\pm \mathrm{SD}$ & mean $\pm \mathrm{SD}$ & \\
\hline Total IPSS & $6.85 \pm 6.52$ & $7.89 \pm 6.63$ & 0.05 \\
\hline QOL score & $2.17 \pm 1.39$ & $2.34 \pm 1.31$ & 0.12 \\
\hline Storage score & $3.14 \pm 2.68$ & $3.47 \pm 2.71$ & 0.13 \\
\hline Frequency & $1.40 \pm 1.47$ & $1.63 \pm 1.44$ & 0.38 \\
\hline Urgency & $0.64 \pm 1.07$ & $0.72 \pm 1.09$ & 0.68 \\
\hline Nocturia & $0.64 \pm 1.01$ & $0.72 \pm 1.09$ & 0.07 \\
\hline Voiding score & $3.68 \pm 4.44$ & $4.37 \pm 4.59$ & 0.23 \\
\hline Incomplete emtying & $1.23 \pm 1.44$ & $1.38 \pm 1.51$ & 0.22 \\
\hline Intermittency & $0.96 \pm 1.50$ & $1.24 \pm 1.60$ & 0.021 \\
\hline Weak stream & $0.95 \pm 1.50$ & $1.24 \pm 1.60$ & 0.22 \\
\hline Straining & $0.56 \pm 1.05$ & $0.67 \pm 1.12$ & 0.014 \\
\hline IPSS grade & & & \\
\hline Mild & $75(69.4 \%)$ & $144(58.3 \%)$ & \\
\hline Moderate & $26(24.1 \%)$ & $85(34.5 \%)$ & $17(6.9 \%)$ \\
\hline Severe & $7(6.5 \%)$ & & \\
\hline
\end{tabular}

Table 2. Comparison of LUTS status in study subjects between MS and non-MS group

In the current study we further stratified patients by their PV and PSA level. The results of total IPSS, storage and voiding scores, were further categorized by PV using $30 \mathrm{~mL}$ as the cutoff point for BPH (Table 3.).

\begin{tabular}{|l|c|c|c|c|c|c|}
\hline & \multicolumn{3}{|c|}{ PV $<30 \mathrm{~mL}$} & \multicolumn{3}{c|}{ PV $>30 \mathrm{~mL}$} \\
\hline & MS (n=60) & $\begin{array}{c}\text { non-MS } \\
(\mathrm{n}=143)\end{array}$ & $\mathrm{p}$ value & MS (n=48) & $\begin{array}{c}\text { non-MS } \\
(\mathrm{n}=103)\end{array}$ & $\mathrm{p}$ value \\
\hline & mean $\pm \mathrm{SD}$ & mean $\pm \mathrm{SD}$ & & mean $\pm \mathrm{SD}$ & mean \pm SD & \\
\hline Total IPSS & $6.24 \pm 6.38$ & $6.86 \pm 5.99$ & 0.34 & $7.6 \pm 6.63$ & $9.32 \pm 7.20$ & 0.045 \\
\hline QOL score & $2.07 \pm 1.49$ & $2.22 \pm 1.27$ & 0.32 & $2.28 \pm 1.24$ & $2.50 \pm 1.35$ & 0.18 \\
\hline Storage score & $2.95 \pm 2.60$ & $2.94 \pm 2.23$ & 0.97 & $3.41 \pm 2.77$ & $4.27 \pm 3.09$ & 0.022 \\
\hline Frequency & $1.33 \pm 1.47$ & $1.47 \pm 1.36$ & 0.37 & $1.47 \pm 1.19$ & $1.84 \pm 1.51$ & 0.050 \\
\hline Urgency & $0.58 \pm 0.93$ & $0.46 \pm 0.82$ & 0.20 & $0.71 \pm 1.11$ & $1.07 \pm 1.30$ & 0.02 \\
\hline Nocturia & $1.01 \pm 0.89$ & $1.28 \pm 0.97$ & 0.97 & $1.23 \pm 0.89$ & $1.35 \pm 1.07$ & 0.31 \\
\hline Voiding score & $3.89 \pm 4.45$ & $3.92 \pm 4.32$ & 0.19 & $4.19 \pm 4.42$ & $5.05 \pm 4.88$ & 0.15 \\
\hline Incomplete emtying & $1.24 \pm 1.60$ & $1.24 \pm 1.41$ & 0.97 & $1.23 \pm 1.22$ & $1.57 \pm 1.61$ & 0.041 \\
\hline Intermittency & $0.77 \pm 1.31$ & $0.95 \pm 1.31$ & 0.22 & $1.18 \pm 1.41$ & $1.30 \pm 1.52$ & 0.52 \\
\hline Weak stream & $0.82 \pm 1.39$ & $1.10 \pm 1.57$ & 0.10 & $1.11 \pm 1.61$ & $1.44 \pm 1.83$ & 0.10 \\
\hline Straining & $0.46 \pm 0.95$ & $0.63 \pm 1.08$ & 0.16 & $0.68 \pm 1.14$ & $0.74 \pm 1.18$ & 0.69 \\
\hline
\end{tabular}

Table 3. LUTS status in enrolled men between MS and non-MS group categorized by PV 
In the larger PV group, total IPSS, storage score and voiding frequency, urgency, and incomplete emptying were significantly lower in the MS vs non-MS group (all $\mathrm{p}<0.05$ ). However, in the smaller PV group, the MS and non-MS groups were comparable on all factors.

Further, in the higher PSA $(>0.93 \mathrm{ng} / \mathrm{mL})$ group, men with MS had significantly lower IPSS, voiding score and less reporting of incomplete emptying and weak stream. Men in the MS group were stratified into 3 groups according to the number of MS risk factors (3, 4 and 5) and their LUTS scores was compared to that of non-MS group (Table 4.).

\begin{tabular}{|l|c|c|c|c|}
\hline & Non-MS & \multicolumn{3}{|c|}{ MS } \\
\hline & $<3$ risk factors & 3 risk factors & 4 risk factors & 5 risk factors \\
\hline Patinents number & 246 & 64 & 30 & 13 \\
\hline Total IPSS & mean \pm SD & mean \pm SD & mean \pm SD & mean \pm SD \\
\hline QOL score & $7.86 \pm 6.63$ & $7.19 \pm 6.60$ & $6.85 \pm 6.53$ & $6.13 \pm 6.41$ \\
\hline Storage score & $2.3 \pm 1.13$ & $2.15 \pm 1.30$ & $2.21 \pm 1.43$ & $2.30 \pm 1.72$ \\
\hline Frequency & $3.48 \pm 2.70$ & $3.29 \pm 2.74$ & $2.90 \pm 2.60$ & $3.30 \pm 2.67$ \\
\hline Urgency & $1.62 \pm 1.43$ & $1.50 \pm 1.48$ & $1.29 \pm 1.46$ & $1.22 \pm 1.57$ \\
\hline Nocturia & $0.72 \pm 1.09$ & $0.68 \pm 0.92$ & $0.54 \pm 0.92$ & $0.65 \pm 1.19$ \\
\hline Voiding score & $1.15 \pm 0.95$ & $1.11 \pm 0.88$ & $1.07 \pm 0.94$ & $1.43 \pm 0.95$ \\
\hline Incomplete emtying & $4.37 \pm 4.59$ & $3.81 \pm 2.52$ & $3.95 \pm 4.54$ & $2.83 \pm 3.97$ \\
\hline Intermittency & $1.37 \pm 1.51$ & $1.27 \pm 1.48$ & $1.37 \pm 1.48$ & $0.83 \pm 1.03 *$ \\
\hline Weak stream & $1.09 \pm 1.41$ & $0.93 \pm 1.37$ & $1.02 \pm 1.44$ & $0.70 \pm 1.26$ \\
\hline Straining & $1.23 \pm 1.60$ & $0.94 \pm 1.48$ & $1.03 \pm 1.60$ & $0.87 \pm 1.39$ \\
\hline OR for moderate/severe LUTS & $0.67 \pm 1.22$ & $0.64 \pm 1.11$ & $0.53 \pm 0.99$ & $0.43 \pm 0.90$ \\
\hline
\end{tabular}

Table 4. The association between LUTS and MS and the number of components of MS in men with and without MS

The negative association between voiding score, severity of LUTS, and MS became more pronounced as the number of MS risk factors increases ( $p$ for trend $<0.01$ ). Compared to the non-MS group, OR for moderate and severe LUTS was significantly lower in patients with 3 (OR 0.61; 95\% CI 0.40-0.94) or 5 (OR $0.32 ; 95 \%$ CI $0.11-0.95)$ MS risk factors.

Men in the MS group had a lower age-adjusted total iPSS ( 7.93 vs $6.75, p=0.027)$ and voiding score (4.39 vs 3.61, $\mathrm{p}=0.083$ ) as well as a trend for a lower storage score (3.5 vs 3.09), $\mathrm{p}=0.059)$ : Finally, compared to the non-MS group, men in the MS group were less likely to experience moderate to severe LUTS (OR 0.58; $95 \%$ CI 0.41-0.83).

\section{Discussion}

According to the Adult Treatment Panel III, the prevalence of MS in middle-aged men was reported to be $21 \%$ to $31 \% 8-10$, which agrees with the prevalence reported in our study (30.5\%). Althugh emerging evedence, particularly from Asian study, suggested no positive assocation between MS and male LUTS6,12, the impact of metabolic factors on male LUTS remained inconclusive.

Although BPH is an important contributor to LUTS in healthy middle-aged men, numerous other factors are associated with development of LUTS. The present study found that age-adjusted total IPSS and voiding scores were significantly lower in the MS group. Additionally, men with MS were to have aproximately 
half the risk of developing moderate to severe LUTS in contrast to men without MS. Interestingly, the negative association between the severity of LUTS and MS became more pronounced as the number of MS factors increased. A similar results was reported by Eom et al.8, who suggested that the early offstage of hyperinsulinemia may have a favorable impact on IPSS and voiding score. The same authors also noted that very high level of $\mathrm{HbA1C}$, representing a prolonged period of hyperinsulinemia, were positively associated with LUTS. Although serum HbA1C level was not associated with the severity of LUTS in our study, we confirm that MS may have a favorable effects on LUTS in generally healthy middle-aged men.

Temml et a15, previously found no positive association between MS and total IPSS, storage and voiding score, or LUTS. The authors suggested that nicotine use and other factors that increase sympathetic nervous system activity might contribute to LUTS5. Additionally, Ohgani et al6 reported that Asian men had less prostate proression and lower LUTS scores compared to men in the west; a finding which may be explained by a different diet and lifestyle.

The current study have several limitations that must be considered when interpreting the results. Because the study sampe consisted of otherwise healthy subjects receiving a medical checkup and most of our study subjects had mild LUTS, it would be inapropriate to generalize the results of other populations. Also, the outcomes in this study were non-adjusted for socioeconomic and lifestyle factors, such s smoking, alcohol consuming or diet quality, which may have an impact on LUTS. Without additional diagnostic procedures, it is impossible to exclude all patients with prostate cancer. Thus the results should be interpreted with caution. Most importantly, the present study is cross-sectional in nature and did consider the effect of time.

\section{Conclusions}

In the present study, we confirmed that MS had favorable effects on LUTS. The association was most pronounced in men with larger prostates and/or higher PSA. Further study with large samples and long term follow-up are warrented to clarify the association between MS and LUTS.

\section{Acknowledgements}

We cordially thank to Natalija Šeparovic, Hypo Alpe Adria, Hypo Facilities Servicies, Belgrade, Serbia for help in statictical analysis and to Mirjana Radenković, Belgrade, Serbia, for the thenical assistance in the preparation of this manuscript.

\section{Literature}

1. Ozden C, Ozdal OL, Urganciogly G, t al. The correlation between metabolic syndrome and prostatic growth in patients with benign prostate hyperplasia. Eur Urol 2007;51:199-203.

2. Hammarsten V, Mc Vary KT, Kaplan SA, et al. Hyperinsulinemia as a risk factor for developing benign prostatic hyperplasia. Eur Urol 2001;39:151-8.

3. Kupelian V, Mc Vary KT, Kaplan SA, et al. Association of lower urinary tract syndrome: results from the Boston Area Community Health Survey. J Urol 2009;182:616-24.

4. Seim A, Hoyo C, Ostbye T, et al. The prevalence and correlation of urinary tracts symptoms in Norvegian men: the HUNT study. BJU Int 2005;96:88-92.

5. Temml C, Obermayr R, Horwich K, et al. Are lower urinary tract symptoms influenced by metabolic syndrome? Urology 2008, 73:544-48.

6. Obyaki K, Hikima N, Horinchi K, et al. Assosiation between lower urinary tract syndrome and male lower urinary tract symptoms in a generally healthy screened population. J Urol 2011;186;175-79.

7. Park HK, Lac HW, Lee RS, et al. Relationship between lower urinary tract symptoms and metabolic syndrome in a community-based elderly population. Urology, 2008; 72;556-60.

8. Eom CS, Park HJ, Cho L, et al. Metabolic syndrome and accompaning hyperinsulinemia have favorable effects on lower urinary tract symptoma in a generally healthy screened population. J Urol 2011;186:175-79. 
9. Villegas R, Perry JG, Creagh D, et al. Prevalence of the metabolic syndrome in middle-aged men and woman. Diabetes Care 2003: 26:1389-99.

10. Welin L, Adlerberth A, Cairdahl K, et al. Prevalence of cardiovascular risk factors and the metabolic syndrome in middle aged men and women in Gothenburg, Sweden. BMC Public Health 2008; 8:403.

11. Rohrmann S, Smart E, Giovannuci E, et al. Association between markers of the metabolic syndrome and lower urinary tract symptoms in the third national health and nutrition examination survey (NHANES III). Int J Obes (Lond) 2005; 29: 310-16.

12. Gao Y, Wang M, Zhang H, et al. Are metabolic syndrome and its components associated with lower urinary tract symptoms? Results from a Chinese male population study. Korean J Urol 2010; 51:631-35.

Corresponding author:

Đorđe Argirović, Outpatient Clinic „Argirovićc“, Urology

Cvijićeva 84 a, 11120 Belgrade, Serbia

Tel.: + 381112788 498, 2788900 